Jasmina Bogićević1

University of Kragujevac, Faculty of Economics

Violeta Domanović ${ }^{2}$

University of Kragujevac, Faculty of Economics
SCIENTIFIC REVIEW ARTICLE doi:10.5937/ekonomika1601069B

Received: January 12, 2015

Accepted: February 23, 2016

\title{
CONTROL IN FUNCTION OF FOREIGN SUBSIDIARY PERFORMANCE EVALUATION
}

\begin{abstract}
The dominant role of the multinational companies (MNCs) in international trade in the late $20^{\text {th }}$ and early $21^{\text {st }}$ century indicates the importance of their management control systems consideration. Management control instruments enable monitoring efficiency not only of MNC as a whole, but also of its subsidiaries. The accounting plays primary roles in the process of management control such as budgeting and creating performance evaluation system. The budget allows determination of foreign subsidiaries and their managers responsible for the identified deviations. The budgeting at MNCs is based on the translation of accounting data denominated in foreign currencies into the parent company currency. In that context, important issue that MNCs address is the choice of appropriate currency. MNCs need to answer the following question: whether budgeting and evaluation of foreign subsidiary's actual result should be done in parent currency or local one.
\end{abstract}

Key words: control, foreign currency translation, exchange rate, budget, performance.

JEL classification: M41, M21.

\section{КОНТРОЛА У ФУНКЦИЈИ ОЦЕНЕ ЕФИКАСНОСТИ ИНОСТРАНИХ ФИЛИЈАЛА ${ }^{3}$}

\begin{abstract}
Апстракт
Доминантна улога мултинационалних компанија (МНК) у међународној трговини крајем 20. и почетком 21. века указује на значај разматрања юихових система управљања контролом. Инструментариј контроле управљања омогућава мониторинг не само ефикасности МНК као иелине, већ и њених филијала. Примарне улоге рачуноводства у прочесу контроле управљања су припрема бучета и креирање система оцене перформанси. Израда бучета у МНК се заснива на превођењу рачуноводствених података исказаних у страној валути у валуту матичне компаније. У том контексту,

\footnotetext{
1 jasminab@kg.ac.rs

${ }^{2}$ violeta.domanovic@gmail.com

${ }^{3}$ The paper is the result of the research done as part of the project no. 41010 "Management and Marketing Research as a Support to Interdisciplinary Projects Realization", financed by the Ministry of Education, Science and Technological Development of the Republic of Serbia.
} 
избор одговарајуће валуте представља значајно питање којим се баве МНК. МНК треба да пруже одговор на следеће питање: да ли припрему буиета и оцену остварених резултата треба извршити у матичној или локалној валути.

Кьучне речи: страна филијала, контрола, превођење стране валуте, курс размене, буиет, перформансе.

\section{Introduction}

The use of management accounting and control systems could be analysed from the framework of performance measurement and performance management. Since the basic premise of the diagnostic control is that the process outputs are measurable, performance measurement might be classified in the category of diagnostic control process. Performance measurement systems are the collection of financial and nonfinancial performance indicators that managers use so they could evaluate their own performance or their units or subordinates. There is a question whether the performance measurement systems are diagnostic or interactive ones. Today, it is widely accepted understanding that performance measurement systems are either diagnostic or interactive. In other words, it is possible to apply the performance measurement systems as a support to control through beliefs systems and boundary systems along with diagnostic and interactive application. The performance measures are the efficient means for the communications about dimensions that are requested, as well as for underlining the acceptable behaviour. If the strategic change is introduced, the accounting control is acceptable in order to supply the requested changes in attitudes and behaviours.

The accounting plays primary roles in the process of management control such as preparing budget and creating performance evaluation system. Numbers in operating budgeting reflect short time frames of company's strategy and allow monitoring of strategy implementation. Budgeting is relevant and frequently applied managerial accounting instrument both at national and international level. This complex issue in national boundaries becomes much more complex in global business arena. Therefore, one of the most important aspects in the preparing budget at the level of MNC is translation of foreign subsidiaries' budgets. In other word, budgeting at MNCs is based on the translation of accounting data denominated in foreign currencies. In that context, important issue that MNCs address is the choice of appropriate currency. MNCs need to answer the following question: whether budgeting and evaluation of the actual result should be done in parent currency or in local currency.

Management control of MNC is primarily concerned with the differences between actual performances and their values in the budget. If the comparison of budget and actual profit is done in local currency, the identified quantitative deviation would result from variations in sales volume and/or price variations in local currency. If the actual profit of foreign subsidiary is compared with its budget value in parent currency, both indicators should be translated into the presentation currency of the parent company. In doing so the appropriate exchange rates are used. If, therefore, the exchange rate 
at the beginning of year is used for translation of budget result and the exchange rate at the end of year is used to translate the actual result, the deviation from the budget value could be caused by variations in the sales volume, variations in local currency prices, as well as changes in exchange rates during the period. In other words, if different exchange rates are used for translation of foreign subsidiary's budget and actual results, deviation of actual profit from budget one may be caused by exchange rate fluctuations. The budget allows determination of foreign subsidiaries and their managers responsible for the identified deviations.

Therefore, the subject of this research paper will be focused on the role of budgeting in foreign subsidiary performance evaluation. More specifically, the study focuses on the concept and types of control and the role of foreign currency translation in operating budgeting at the level of MNC. The main goal of the paper is to point out the key roles of budgeting in the process of performance evaluation. The significant research objective is to show that the deviation due to changes in exchange rates, identified by comparing the budget and actual result, could be avoided by using the same exchange rate to translate both the budget and actual results. Thus, the paper is structured in two parts. The first part deals with concept and types of control, and the second one is devoted to the significance of foreign currency translation in the budgeting process.

In the paper, it is applied the qualitative methodology, established on studying and descriptive analysis of the research problem in the area of accounting and business economics. By the methods of synthesis and deduction, there will be synthesizing of the different attitudes, on the basis of which there would be general conclusions derived related to the role of control in foreign subsidiary performance evaluation.

\section{The concept and types of control}

Control is the process of making sure that the business activities are to fit in the plan and that defined aims and objectives are to be realized. Peter Drucker (1964) made a distinction between the words "controls" and "control". The word "controls" means measurement and information, while the word "control" means the direction. "Controls" encompass all methods and procedures which direct the employees toward the organizational aims achievement (for example, the job description, operating instructions, procedures and budgets for the employees training). Such a control is called administrative and it could be said formal one. There are also and social and informal control, which the individuals mutual perform - for example, procedures that small groups use in order to regulate the performance of their members and in order to redirect the individuals' behaviour if there are deviations of their performance from group standards. In addition to administrative (formal) and social (informal) control, there are also other types of control: ex ante, cybernetic, binary, ex post, strategic, management control and operating control, control based on accounting reports, control by performance measures, budgetary control (Krstić, 2012; Domanović, 2014). Krstić (2012) accentuate different approaches and these are: market approach to control, which accentuates external, market mechanisms - competition, in order to define measurable standard for performance control, that is for quantitative and qualitative comparison and deviations identification; bureaucratic control, which is directed toward strict hierarchy, 
rules, prescriptions, procedures, policies, standardization of activities, good established budgets in order to ensure that the employees behave in an adequate manner in order to fulfil standards/defined target levels of financial and nonfinancial performances; and clan control, which is regulated on basis of common formed and established values, norms, beliefs and other key aspects of organizational culture.

Otley (1999) distinguished "'management control" from "strategic planning" and "'operational control". Anthony et al. (1989) introduced the management control system. The processes of the management control are: strategic planning and control, management control and task control. Strategic planning and control deal with long term aims and objectives in terms of their defining and finding the way of their realization. These are directed toward external issues. The task control is more routine process, which make possible that everyday activities would be performed effectively and efficiently (Anthony et al., 1989, 11). Management control connects these two elements. This is the process, which ensures that the strategy is expressed in the tasks that are performed. Management control process is the process in which the managers at all levels supervise the employees in order to implement the defined strategy. This is also the process of detecting and correcting the unintentionally mistakes of the performances and intentionally irregularities. Hence, the control model is the cybernetic one although there is very little cybernetics included.

Simons (2000) defined the management control systems as formal, information based routines and procedures that managers apply in order to maintain or change the organizational activities pattern. Despite its confidentiality and widespread acceptance, Simon's model of management control has numerous serious limitations (Berry et al., 2005). In its essence, Anthony's model stresses the financial aims and, through the budgetary control, has been usually concentrated on forthcoming 12 months. Thus, this model pays a little attention to long term aims and objectives. Since this model ignores the issues like business environment and positioning the company in relation to other entities, it did not succeed to adjust the ideas that are of fundamental significance for the concepts of the strategy and control.

Traditionally, the strategic control supplies that employees' behaviour is consistent with the defined strategy (Merchant, 1985). This could be considered as the control of the strategy implementation. Besides, the strategic control implies and systematic check whether the present strategy is relevant in terms of the changeable circumstances. The role of the strategic control system is to enable the top management to reply on unpredictable external and internal challenges by strategy redefining. This could be considered as the control of relevance. The strategies that managers define in advance deliberately as well as unintentionally, incremental strategies should be the subject of the control.

There are differences between the strategic control and budgetary control (Domanović, 2010; Domanović, 2014). Strategic control demands more data from different sources, especially external ones and might deal with the competitive benchmarks for comparison and nonfinancial measures, as well as with long term outcomes. Strategic control could be less precise and formal then the budgetary control and deals more with the accuracy of premises on the basis of which the management control is based than with the quantitative deviations from the standards. Operating control implies the employees' performance evaluation at the operating level by the middle managers.

Simon's (2000) model of strategic control is based on four control levers: beliefs systems, boundary systems, diagnostic control systems and interactive control systems. 
The belief systems are used in order to increase the core values connected with the business strategy and inspire the research for new opportunities in accordance with these values. The boundary systems reduce the risks of setting the limits to the strategic undesirable behaviours. Through the diagnostic control system, the critical success factors are communicated and supervised. Finally, the interactive control systems are used in order to discuss about strategic uncertainty and get new strategic replies on changeable environment. While the beliefs systems and interactive control are used in order to encourage innovative behaviour, the boundary systems and diagnostic control are used in order to determine that the employees behave as it is defined by established rules and plans.

Tessier \& Otley (2012) examined Simon's Levers of Control (LOC) framework taking a holistic approach which consists of analyzing the internal consistency of the framework's components and also comparing them with other similar concepts in the literature. They introduced two groups of actors, managers (intention) and employees (perception) and focused mainly on the former. Managerial intentions are comprised of three levels of choice: (1) types of control (social and technical), (2) objectives of controls (performance or compliance) which are regrouped into four control systems operating at two organizational levels (operational and strategic performance control systems and business conduct and strategic boundaries) and (3) other choices regarding use of controls (interactive/diagnostic), role of controls (enabling/constraining) and consequences linked to controls (rewards/punishments).

Otley (1999) points out that attempting to design control systems without having a detailed knowledge of how the business works is likely to prove a recipe for disaster. Design of the management control system with the aim of the corporate efficiency evaluation includes a clear identification of whom, what and when. The reply on the question who indicates who is interested in the process of corporate efficiency evaluation. There are four recipients of the performance reports: (1) owners and managers, (2) creditors, (3) local government, and (4) employees. Everyone has a different understanding of desired performances (Domanović, 2014). The second aspect of the management control is what the subject of the evaluation is. It is usual to evaluate an individual manager, so the effectiveness and efficiency of his performances could be evaluated. Alternatively, the subject of the evaluation might be the strategic business unit, which is under control of the manager in terms whether it is necessary or not to expand or divest the strategic business unit. The subject of the evaluation might also be the team of the managers. The managers' performances might be compared with the performances of other managers or with own performances in previous years. The third aspect of the management control is when the performance evaluation should be performed. Firstly, the evaluation might be performed on basis of whether the resources that managers use or on basis of their results. The first approach use master budget and the second one use the flexible budget. The first approach is ex ante and other ex post.

The use of management accounting and control systems could be analysed from the framework of performance measurement and performance management. Since the basic premise of the diagnostic control is that the process outputs are measurable, performance measurement might be classified in the category of diagnostic control process. Performance measurement systems are the collection of financial and nonfinancial performance indicators that managers use so they could evaluate their own 
performance or their units or subordinates. Jordan \& Messner (2012) examined to which extent managers care about the design characteristics of performance indicators and other control systems with the help of the framework of enabling and coercive control. They discussed about enabling and coercive control. Management control will be regarded as coercive (rather than enabling) at least at some point in time. The introduction of a new control system can easily create feelings of coercion among middle managers and employees, but it does not mean that it has to remain being seen as coercive.

There is a question whether the performance measurement systems are diagnostic or interactive ones. Today, it is widely accepted understanding that performance measurement systems are either diagnostic or interactive. In other words, it is possible to apply the performance measurement systems as a support to control through beliefs systems and boundary systems along with diagnostic and interactive application. The performance measures are the efficient means for the communications about dimensions that are requested, as well as for underlining the acceptable behaviour. If the strategic change is introduced, the accounting control is acceptable in order to supply the requested changes in attitudes and behaviours.

The concept of control is a very fascinating topic since it could be viewed from economic, social, behavioural, cross-national and cultural aspects. It is interesting to consider control in multinational companies. Bedford \& Malmi (2015) examined how control mechanisms combine depending on the contexts in which they operate. They examined how accounting combined with a wide variety of control arrangements and contexts and found that in contexts characterized by uncertainty, accounting is activated in an interactive fashion and combines with organic and flexible-bureaucratic configurations. They also stress that the design and use of accounting mechanisms depend on knowledge of contextual conditions as well as on the wider control structure in which those mechanisms reside.

\section{The role of foreign currency translation in budgeting}

The contribution of accountants in the management control process is realized in two ways. First of all, accountants prepare budget as a tool which reflects short term horizons of company's strategy and makes possible monitoring of implemented strategy. They also participate in creating the performance evaluation system.

Numerous studies show that budgeting, as relevant and frequently applied managerial accounting instrument in international business, is based on the translation of accounting data denominated in foreign currencies. In an accounting context, foreign currency translation is the restatement of accounting data expressed in one currency into another (Bogicevic, 2013, 138). Appropriate formulated standards for assessing performance can stimulate managers to take actions that will contribute to increase efficiency and achieve company's objectives. Standards used in the control process of company performance as a whole, its segments or areas of responsibility, as well as their managers are adopted by opting of objectives in the budget. As budget allows determination of responsibility for company's units and managers, it represents a standfast for the performance assessment.

As a rule MNCs simultaneously use multiple financial measures, non-financial measures or some creative mixture of the two to assess performance. Relevant financial 
measures of performance involve: sales growth, net profit, cost reduction, return on sales, and return on investment (Doupnik \& Perera, 2007). Non-financial measures of foreign subsidiary that are not based on financial statement's algebra include: market share increasing, quality control, productivity improvement, relation with the government of the host country and parent company, employee development and safety (Choi \& Czechowich, 1983, 17). Several research studies conducted in the USA and United Kingdom over the period 1980 to 1990 highlighted the importance of financial measures in foreign subsidiary performance evaluation. Surveyed managers of MNCs pointed out that the most commonly used financial measures for subsidiary performance evaluation were profit, return on investment and budget compared to actual profit with a slightly modifications in rank order. In this regard Doupnik \& Perera (2007) pointed out that profit is the top financial measure used by MNCs with headquarters in the USA. By contrast, the results of a 1988 survey of UK MNCs indicated that top financial measure is not absolute amounts of profit, but budget compared to actual profit (Doupnik \& Perera, 2007). The significance of profit in accounting literature as performance criteria arises from the fact that it is treated not only as a single measure, but as a basis for identifying other performance measures (Bogicevic et. al, 2013). Management control of a company is primarily concerned with the differences between actual performances and their values in the budget. In that way budget allows determination of subsidiaries and their managers responsible for the identified deviations.

The key issue in the assessing foreign subsidiary performance relates to the choice of currency. Analogously previously highlighted the importance of currency choice in assessing foreign subsidiary performance, MNCs must make a currency choice for the purpose of preparing the budget. In other words, MNCs must solve the next dilemma: whether budgeting and evaluation of the actual (realized) result should be done in parent currency or in local one. If the comparison of budget and actual profit is done in local currency, the identified quantitative deviation would result from variations in sales volume and/or price variations in local currency. If the actual profit of foreign subsidiary is compared with its budget value in parent currency, both indicators should be denominated into the presentation currency of the parent company. The appropriate exchange rates are used for the purpose of that translation. Different exchange rates could be used in that process, such as the exchange rate at the beginning of the year, the exchange rate at the end of the year, and/or average exchange rate. If, therefore, the exchange rate at the beginning of the year is used for translation of budget result and the exchange rate at the end of the year is used to translate the actual result, the deviation from the budget value could be caused by variations in the sales volume, variations in local currency prices, as well as changes in exchange rates during the period. In other words, if different exchange rates are used for translation of budget and actual results, deviation of actual profit from budget one may be caused by exchange rate fluctuations. These relations can be summarized in Table 1 . 
Table 1. Translation of profit in local currency into profit in parent currency

\begin{tabular}{|c|c|c|c|}
\hline $\begin{array}{l}\text { Budget profit in local } \\
\text { currency }\end{array}$ & $\mathrm{x}$ & Beginning exchange rate & $=$ Budget profit in parent currency \\
\hline \multicolumn{4}{|c|}{ versus } \\
\hline $\begin{array}{l}\text { Actual profit in local } \\
\text { currency }\end{array}$ & $\mathrm{x}$ & Ending exchange rate & $=$ Actual profit in parent currency \\
\hline \multicolumn{4}{|c|}{$\begin{array}{l}\text { Variance }=\mathrm{f} \text { (sales volume variance and local currency price variances }) \\
\text { Variance }=\mathrm{f}(\text { sales volume variance, local currency prices and exchange rate variance) }\end{array}$} \\
\hline
\end{tabular}

Source: Adapted from Doupnik, T. \& Perera, H., (2007). International Accounting, International Edition, New York, McGraw-Hill.

It is obvious that currency volatility poses a great challenge to foreign subsidiary performance assessing and budgeting. In that case the question arises as to whether the manager of foreign subsidiary should be considered accountable or not for exposure to currency risk. In a situation when a comparison of budget and actual aggregates is done in parent currency, the question arises as to whether deviation from plan due to changes in exchange rates should be included in performance evaluation of foreign subsidiary and its managers. The answer to the above question should be linked to the responsibility of local managers to currency hedging. If foreign managers have control over the currency hedging, they would be considered responsible for part of the deviations arising due to changes in currency volatility. In that case, it is recommended to translate both budget and actual result in parent currency, and the responsibility for deviations due to changes in exchange rates should be located to foreign subsidiary manager(s). Conversely, if foreign subsidiary managers do not have control over exposure to foreign exchange risk, it is recommended to use result denominated in local currency for assessing foreign subsidiary performance.

As MNCs usually centralize the activities of currency risk management, individual foreign subsidiary is not responsible for currency hedging. Although foreign subsidiaries as a rule don't manage their currency risk exposure, MNC headquarters is interested in their financial position and profitability. However, the headquarters is interested in assessing the performance of its subsidiaries in various parts of the world on the uniform basis that is the currency of the parent company. Although foreign exchange risk could not be attributed to an individual subsidiary, both types of its result, budget and actual, denominated in local currency should be translated in parent currency. In doing so, preparing the budget and translation process should be based on a single exchange rate, which can be (Doupnik \& Perera, 2007):

1. The real exchange rate in the period of budget preparation;

2. The projected future exchange rate during the preparation of the budget;

3. The real exchange rate at the end of the budget period.

On the basis of these exchange rates it is possible to make a nine combination for translation of budget and actual results of which only five could be used in performance assessment. Combinations of exchange rates are as follows (Lessard \& Lorange, 1977, 628): 
Exhibit 1. Combinations for translation of budget and actual results

\begin{tabular}{|l|c|c|c|}
\hline & \multicolumn{3}{|c|}{ Rate used to track actual performance to budget } \\
\hline \multicolumn{1}{|c|}{ Rate used for determining budget } & $\begin{array}{c}\text { Actual at } \\
\text { time of budget }\end{array}$ & $\begin{array}{c}\text { Projected at time of } \\
\text { budget }\end{array}$ & $\begin{array}{c}\text { Actual at end of } \\
\text { period }\end{array}$ \\
\hline Actual at time of budget & 1 & $/$ & 4 \\
Projected at time of budget & $/$ & 3 & 5 \\
Actual at end of period & $/$ & $/$ & 2 \\
\hline
\end{tabular}

Source: Lessard, D. \& Lorange, P. (1977) Currency Changes and Management Control: Resolving the Centralization/Decentralization Dilemma, Accounting Review, 628.

The meaningful, numbered combinations of exchange rates vary according to the exchange rate effects on performance evaluation and responsibility of foreign subsidiary managers for currency risk. Blake \& Hossain $(1996,279)$ pointed out that different exchange rate combinations to set budgets and track performance give rise to differing managerial responses. These five combinations that differ in scope of management responsibility for the exchange rate component of the budget deviation can be explained as follows (Doupnik \& Perera, 2007):

1. The first combination means the translation of budget and actual results at the effective spot exchange rate in the period of budget preparation. In that case a total deviation from the planned results is a function of sales volume variance and/or changes in local currency prices in local. Although exchange rate changes, management doesn't bear responsibility for currency volatility. However, there are minor incentives to take account of projected exchange rate changes in making operation decisions. This alternative does not differ from the assessment of results in local currency.

2. The second combination relates to translation of budget and actual results at the effective spot exchange rate at the end of the budget period - this combination is interpreted in the same manner as explained previously one.

3. The third combination is based on translation of budget and actual results at a projected exchange rate at the time the budget is prepared. This alternative, as the previous two, implies that a total deviation from the planned results is a function of sales volume variations and price changes in local currency. Although managers are not responsible for the exchange rate component of budget variance, this alternative motivates them to consider anticipated changes in exchange rates and take them into consideration in the drafting of their operational plans; that is why this combination is the most propagated in accounting literature.

4. The fourth combination means that budget and actual result are translated using different exchange rates. In particular, budget is translated at the beginning of period exchange rate and actual result at the end of period exchange rate. Hence, the deviation from budget can be decomposed into sales volume variance, 
local currency prices changes, and exchange rate fluctuations. Unlike previous combinations, managers can be held accountable for the effects of currency volatility. If there is a natural hedging at the level of $\mathrm{MNC}$ as a whole (one foreign subsidiary has the receivables and the other one has liability, both will be due simultaneously, denominated in the same foreign currency, and at the same amount), local managers will be encouraged to protect themselves from various types of foreign exchange risks (transaction, translation and economic exposure).

5. Under this combination the budget and actual result are translated using the projected ending exchange rate and the actual ending rate, respectively. The total deviation from budget result is a function of sales volume, price variations in local currency and the unanticipated changes in exchange rate. It is noteworthy that managers of subsidiary include projected exchange rate changes in operating plan and are held responsible for their attitudes to unexpected exchange rate changes.

In order to empirically illustrate previously explained combinations of exchange rates for remeasurement the budged ant actual results, we slightly adapted Doupnik \& Perera (2007) simplified example and started from MNC headquartered in Italy with its subsidiary abroad (outside the Eurozone). The amounts of relevant aggregates denominated in foreign currency (FC) are as follows:

\begin{tabular}{l} 
Budget Sales ----------- 200 FC \\
Budget Expenses -------- 180 FC \\
\hline Budget result /profit ------ $20 \mathrm{FC}$
\end{tabular}

Fluctuations in exchange rates of parent currency (euro) against foreign currency during the budget period can be summarized as follows:

- actual exchange rate at time of budget preparation---------- $1,00 \mathrm{FC}=2 \mathrm{PC}$

- projected ending exchange rate--------------------------- 1.00 FC=1.80 PC

- actual exchange rate at end of period ------------------------1, 00 FC=1.40 PC

Assuming that the actual result of a foreign subsidiary in foreign currency is the same as budgeted, the effects of translation of budget and actual results of foreign subsidiaries from local currency (FC) into parent currency (PC) can be presented in numerical example. Since the budget and actual amounts can be translated using the same or different exchange rates, combinations with and without exchange rate variance are separately presented in Exhibit 2 and Exhibit 3, respectively.

Exhibit 2. Translation of budget and actual results of foreign subsidiaries into parent currency without exchange rate variance

\begin{tabular}{|l|l|l|l|l|l|l|}
\hline \multirow{2}{*}{} & \multicolumn{6}{|c|}{ Combinations without exchange rates variance } \\
\cline { 2 - 8 } & \multicolumn{2}{|c|}{1} & \multicolumn{2}{c|}{2} & \multicolumn{2}{c|}{3} \\
\cline { 2 - 7 } & Budget & Actual & Budget & Actual & Budget & Actual \\
\hline Exchange rates & $2,0 P C$ & $2,0 P C$ & $1,4 P C$ & $1,4 P C$ & $1,8 P C$ & $1,8 P C$ \\
\hline Sales & 400 & 400 & 280 & 280 & 360 & 360 \\
\hline Expenses & 360 & 360 & 252 & 252 & 324 & 324 \\
\hline Result/Profit & 40 & 40 & 28 & 28 & 36 & 36 \\
\hline Deviation & 0 & & 0 & & 0 & \\
\hline
\end{tabular}

Source: Adapted from Doupnik, T. \& Perera, H., (2007). International Accounting, International Edition, New York, McGraw-Hill. 
As shown in Exhibit 2 these three combinations are based on using the same exchange rate for translation of the budget and actual results. In these combinations there is no exchange rate deviation. In other words budget deviation cannot be a function of exchange rate changes. Hence, managers of foreign subsidiary are not held accountable for exchange rate changes. Exchange rates have no effect on assessing foreign subsidiary performance. Possible deviations from the budget (if foreign subsidiary did not meet its sales volume and expense target in terms of foreign currency) occur due to changes in sales volume, sales price, purchase price and other factors that determine the level of expenses.

Doupnik \& Perera (2007) cited the results of only one conducted study (The 1989 Business International Study „Evaluating the performance“) according to which only 14 percent of U.S. companies indicated using the same exchange rate to translate both the budget and actual results. The majority of MNCs included in this study pointed to the use of different exchange rates to translate the budget and actual results. The Exhibit 3 shows the combinations in which the different exchange rate are used for translating the budget and actual figures

Exhibit 3. Translation of budget and actual results of foreign subsidiaries into parent currency with exchange rate variance

\begin{tabular}{|l|c|c|c|c|}
\hline \multirow{2}{*}{} & \multicolumn{4}{|c|}{ Combinations with exchange rates variance } \\
\cline { 2 - 5 } & \multicolumn{2}{|c|}{4} & \multicolumn{2}{c|}{5} \\
\cline { 2 - 5 } & Budget & Actual & Budget & Actual \\
\hline Exchange rates & $2,0 \mathrm{PC}$ & $1,4 \mathrm{PC}$ & $1,8 \mathrm{PC}$ & $1,4 \mathrm{PC}$ \\
\hline Sales & 400 & 280 & 360 & 280 \\
\hline Expenses & 360 & 252 & 324 & 252 \\
\hline Result/Profit & 40 & 28 & 36 & 28 \\
\hline Deviation & -12 & & -8 & \\
\hline
\end{tabular}

Source: Adapted from Doupnik, T. \& Perera, H., (2007). International Accounting, International Edition, New York, McGraw-Hill.

Unlike combinations 1, 2 and 3, there is an exchange rate deviation in both combinations shown in Exhibit 3. Since the observed foreign subsidiary made entirely planned amount of sales and expenses, the deviation that occurs in the parent currency arises solely from exchange rate fluctuations. The exchange rate deviation of PC12 is obtained by multiplying the actual profit in foreign currency (FC20) and change in the ending compared to the beginning exchange rate $(\mathrm{PC} 0,60)$. The exchange rate deviation in combination 5 is PC8. It is equal to the actual amount of profit denominated in foreign currency (FC20) multiplied by the unexpected change in the exchange rate in the amount of PC0, 40 (PC1, 40-PC1, 80).

Finally, it can be concluded that the deviation due to changes in exchange rates, identified by comparing the budget and actual result, can be avoided by using the same exchange rate to translate both the budget and actual results. The consideration of the effects of changes in exchange rates on the budget process has confirmed the undeniable importance of foreign currency translation in the implementation of this relevant managerial accounting instrument. 
There are a number of other macro-economic variables affecting the foreign subsidiary budgeting and the performance evaluation system (Domanović \& Bogićević, 2009). The most important among them are different rates of inflation, and interest rates. Rivera \& Milani (2011) accentuated that foreign exchange rates, interest rates, and inflation make so-called "Bermud Triangle " which affects multinationals' budgets. Therefore, our next research will be devoted to understanding the simultaneous impact of these external factors on multinationals' budget.

\section{Conclusion}

The concept of control is a very fascinating topic since it could be viewed from economic, social, behavioural, cross-national and cultural aspects. It is interesting to consider control in multinational companies. Bedford \& Malmi (2015) examined how control mechanisms combine depending on the contexts in which they operate. They examined how accounting combined with a wide variety of control arrangements and contexts and found that in contexts characterized by uncertainty, accounting is activated in an interactive fashion and combines with organic and flexible-bureaucratic configurations. They also stress that the design and use of accounting mechanisms depend on knowledge of contextual conditions as well as on the wider control structure in which those mechanisms reside. Budgeting represents relevant and frequently applied managerial accounting mechanism in international business.

MNCs use multiple financial and non-financial measures in performance evaluation. The most commonly used financial measures for subsidiary performance evaluation are profit, return on investment and budget compared to actual profit. Management control of the company is primarily concerned with the differences between actual performances and their values in the budget. In that way budget allows delegation of subsidiaries and their managers responsible for the identified deviations. Therefore, it is not surprising that the budget is qualified as a point of reference for assessing the performance.

MNC headquarters is interested in assessing the performance of its subsidiaries in various parts of the world on the uniform basis that is the currency of the parent company. Therefore, both types of foreign subsidiary results, budget and actual, denominated in local currency should be translated into parent currency. For that purpose, it should be used a single exchange rate, such as: the real exchange rate in the period of budget preparation, the projected future exchange rate during the preparation of the budget, and the real exchange rate at the end of the budget period.

On the basis of these exchange rates it is possible to make a five meaningful combination for translation of the budget and actual results that could be used in the foreign subsidiary performance assessment. If combination is based on using the same exchange rate for translation of the budget and actual results, there is no exchange rate deviation. Hence, managers of foreign subsidiary are not held accountable for exchange rate changes. Exchange rates have no effect on assessing foreign subsidiary performance. If budget and actual results are translated using different exchange rates, the deviation from the budget can be decomposed into sales volume variance, local currency prices changes, and exchange rate fluctuations. Managers can be held responsible for the effects of currency volatility. 


\section{References}

Anthony, R. N., Dearden, J., \& Bedford, N., (1989). Management Control Systems, 6th edition. Irwin: Homewood, III.

Bedford, S. D. (2015). Configurations of control: an exploratory analysis. Management Accounting Research, 27, 2-26.

Berry, J., Broadbent, A., \& Otley, D. (2005). Approaches to control in the organizational literature. In J. Berry, A.

Blake, J. \& Hossain, M., (1996). Readings in International Accounting, International Thompson Business Press, London.

Bogićević, J., Domanović, V. \& Manić, S., (2013). The impact of foreign currency translation on foreign subsidiary performance, (2013). 513-525, Conference proceedings 2nd International Scientific Conference Contemporary Issues in Economic, Business, and Management, 513-525.

Bogićević, J., (2013). Accounting implications of foreign currency transactions translation and hedging, Economic horizons, Vol. 13, No 2, 137-15.

Choi, F. \&Czechovicz, I. (1983). Assessing Foreign Subsidiary Performance: A Multinational Comparison, Management International Review, 23, 12-20.

Domanović, V. (2010). Balanced Scorecard-mogućnosti i efekti primene. Kragujevac: Ekonomski fakultet Kragujevac.

Domanović, V. (2014). Uloga kontrole u procesu upravljanja efikasnošću preduzeća. Revizor, 17(65), 23-39.

Domanović, V., \& Bogićević, J. (2009). The Role of Accounting in Foreign Subsidiary Performance Evaluation, Economic Themes, 4, 113-126.

Domanović, V., \& Bogićević, J. (2010). Izbalansirana karta rezultata u funkciji merenja efikasnosti inostranih filijala. Revizor, 13(50), 23-35.

Doupnik, T. \& Perera, H., (2007). International Accounting, International Edition, New York, McGraw-Hill.

Drucker, P. (1964). Control, controls and management. In C. P. Bonini, R. K. Jaedicke, R. K., \& H. M. Wagner (Eds.), Management Control: New Directions in Basic Research (pp. 289-296). New York: John Wiley.

Jordan, S., \& Messner, M. (2012). Enabling control and the problem of incomplete performance indicators. Accounting, Organizations and Society, 37, 544-564.

Krstić, B. (2012). Uloga strategijske kontrole u unapređenju poslovnih performansi. Niš: Ekonomski fakultet Niš. Lessard, D. \& Lorange, P. (1977) Currency Changes and Management Control: Resolving the Centralization/Decentralization Dilemma, Accounting Review, 628-637.

Merchant, K. A. (1985). Control in Business Organizations. Pitman.

Otley, D. (1999). Performance management: a framework for management control systems research. Management Accounting Research, 10, 363-382.

Rivera, J., \& Milani, K., (2011). Budgeting for International Operations: Impact on and Integration with Strategic Planning, Management Accounting Quarterly, 12, (4), 1-13 
Simons, R. (2000). Performance Measurement and Control Systems for Implementing Strategy: Text and Cases. NJ: Prentice Hall, Englewood Cliffs.

Tessier, S., \& Otley, D. (2012). A conceptual development of Simon's level of control framework. Management Accounting Research, 23, 171-185. 